\title{
Effect of intensive epilimnetic withdrawal on the phytoplankton in a (sub)tropical deep reservoir
}

\author{
Man ZHANG, ${ }^{1,2}$ Qiu-Qi LIN, ${ }^{1}$ Li-Juan XIAO, ${ }^{1}$ Sheng WANG, ${ }^{3}$ Xin QIAN, ${ }^{3}$ Bo-Ping HAN ${ }^{1 *}$ \\ ${ }^{1}$ Department of Ecology and Institute of Hydrobiology, Jinan University, Guangzhou 510632; ${ }^{2}$ College of Fisheries, Henan Normal \\ University, Xinxiang 453007; ${ }^{3}$ State Key Laboratory of Pollution Control and Resources Reuse, School of the Environment, Nanjing \\ University, Nanjing 210093, China \\ *Corresponding author: tbphan@126.com; tbphan@jnu.edu.cn
}

\begin{abstract}
Withdrawal is an important process in reservoir hydrodynamics, removing phytoplankton with flushed water. Zooplankton, the grazers of phytoplankton, having longer generation times, are even more susceptible than phytoplankton to flushing loss, therefore phytoplankton are affected not only by abiotic conditions linked to hydrodynamics but also by zooplankton due to weakened grazing pressure. During the Asian Games (November 12-27, 2010 in Guangzhou, China), two intensive epilimnetic withdrawals were conducted in Liuxihe, a deep canyon-shaped reservoir. To examine the influence of the intensive epilimnetic withdrawals on the phytoplankton community, a seven-week field observation and a hydrodynamic simulation were carried out. The observation was divided in two stages: stage 1 represented partial surface vertical mixing period, and stage 2 represented intensive epilimnetic withdrawal period. It was found that phytoplankton abundance and biomass declined with water temperature and partial surface vertical mixing in stage 1. However, the intensive epilimnetic withdrawal reversed this decreasing trend and increased phytoplankton biomass and abundance in stage 2. Phytoplankton showed a higher rate of composition change in stage 2. A numerical model (DYRESM-CAEDYM) simulated scenarios with and without epilimnetic withdrawal to test their effects on abiotic factors (water temperature, suspended sediment and soluble reactive phosphorus) for phytoplankton. The results showed no obvious difference in the abiotic factors between the two scenarios during stage 2. We therefore suggested that the abiotic factors in the water column were probably driven by a seasonal pattern, not by epilimnetic withdrawal. It is likely that the intensive epilimnetic withdrawal could remove large crustaceans. The reduced grazing pressure probably explained the increase of phytoplankton biomass and abundance after the withdrawal. Thus, we suggest that reservoir operation should pay more attention to grazing from large crustaceans. It is recommended that, in the management of reservoirs, intensive epilimnetic withdrawal during autumn should be avoided in order to control excessive phytoplankton in the tropics and subtropics.
\end{abstract}

Key words: epilimnetic withdrawal, flushing, zooplankton grazing, phytoplankton, simulation.

Received: December 2012. Accepted: April 2013.

\section{INTRODUCTION}

The biomass and species composition of the phytoplankton community are of fundamental importance for aquatic system metabolism. Factors structuring the phytoplankton are chemical (nutrients, particularly phosphorus), physical (temperature, underwater light climate) and biological (grazing, competition). They are regulated by hydrodynamics, especially in reservoirs (Han et al., 2000; Calijuri et al., 2002; Burford et al., 2012). Epilimnetic withdrawal is an important process that affects hydrodynamics in reservoirs (Hamilton and Schladow, 1997; Çalişkan and Elçi, 2009; Wang et al., 2012a). The mixing regime and distributions of biota are sensitive to the depth and dynamics of epilimnetic withdrawal.

Epilimnetic withdrawal is capable of removing large amounts of phytoplankton and zooplankton from water bodies with high flushing rates during the periods of high discharge. However, the extent of removal depends on the flushing rate. For example, Barbiero et al. (1997) found that surface withdrawal was unsuccessful in controlling phytoplankton biomass. Compared to phytoplankton, zooplankton with longer generation times are more susceptible to flushing loss (Pace et al., 1992). Under an intermediate flushing rate, zooplankton rather than phytoplankton are suppressed and their grazing effect is limited, which may result in an increase in phytoplankton abundance and biomass. Therefore the effects of the epilimnetic withdrawal on the phytoplankton vary not only with flushing loss, but also with their interaction with zooplankton.

Alternatively, epilimnetic withdrawal could affect phytoplankton by modifying the profiles of water temperature, nutrients and underwater light climate (Naselli-Flores and Barone, 2005; Cheng and Kao, 2008; Chien et al., 2009). Epilimnetic withdrawal directly removes warm surface water and preserves cool and dense hypolimnetic water. Such an operation permits a hypolimnetic accumulation of phosphorus (Cooke et al., 1993; Barbiero et al., 1997; Nürnberg, 2007; Çalıskan and Elçi, 2009; Wang et 
al., 2012a) and could mix the nutrients with the epilimnion. Surely these abiotic factors (water temperature, nutrient dynamics and underwater light climate) exert effects on the phytoplankton.Many reservoirs have been built in southern China since the 1950s (Han and Liu, 2011). The function of most of the reservoirs switched to supplying drinking water after 1978 when China started economic reforms that resulted in heavy pollution. As water demand increases, increasing withdrawal might be expected to impact ecosystem dynamics through modification of abiotic and even biological processes. However, this issue is neglected in management of water quality, partly because of the difficulty in recognizing such an impact in highly dynamic systems. During the Asian Games held in Guangzhou (November 12-27, 2010), a huge amount of water was suddenly required from two large reservoirs (Liuxihe and Feilaixia). Two intensive epilimnetic withdrawals were conducted at Liuxihe reservoir, a deep impoundment located in the upper reaches of Liuxihe river, to meet the water requirement. To elucidate the underlying mechanisms how the phytoplankton community responds to such intensive epilimnetic withdrawals, two questions were addressed and tackled in this study: i) how intensive epilimnetic withdrawals affect the abiotic factors (phosphorus, water temperature, suspended sediment) for phytoplankton? ii) how flushing affects zooplankton (flushing loss)?

\section{METHODS}

\section{Study site}

Liuxihe reservoir $\left(23^{\circ} 45 \mathrm{~N}, 113^{\circ} 46 \mathrm{E}\right)$ is a monomictic, mesotrophic canyon-reservoir, located on the Tropic of Cancer in a tropical monsoon climate (Fig. 1). The catchment area of the reservoir covers a surface of $539 \mathrm{~km}^{2}$ and the water surface is $15 \mathrm{~km}^{2}$ at maximum storage capacity, which corresponds to a volume of $3.25 \times 10^{8} \mathrm{~m}^{3}$. Maximum depth of the open water zone is $73 \mathrm{~m}$, and the average depth is $21.3 \mathrm{~m}$ (Lin et al., 2009). The high water level is $235 \mathrm{~m}$ asl (46 m depth at the dam) and the minimum water level is $213 \mathrm{~m}$ asl ( $24 \mathrm{~m}$ depth at the dam). The reservoir is fed by Lutian and Yuxi rivers, which drain a catchment area of $264.4 \mathrm{~km}^{2}$ and $192.3 \mathrm{~km}^{2}$, respectively. Most of the outflow is released from the normal outlet for

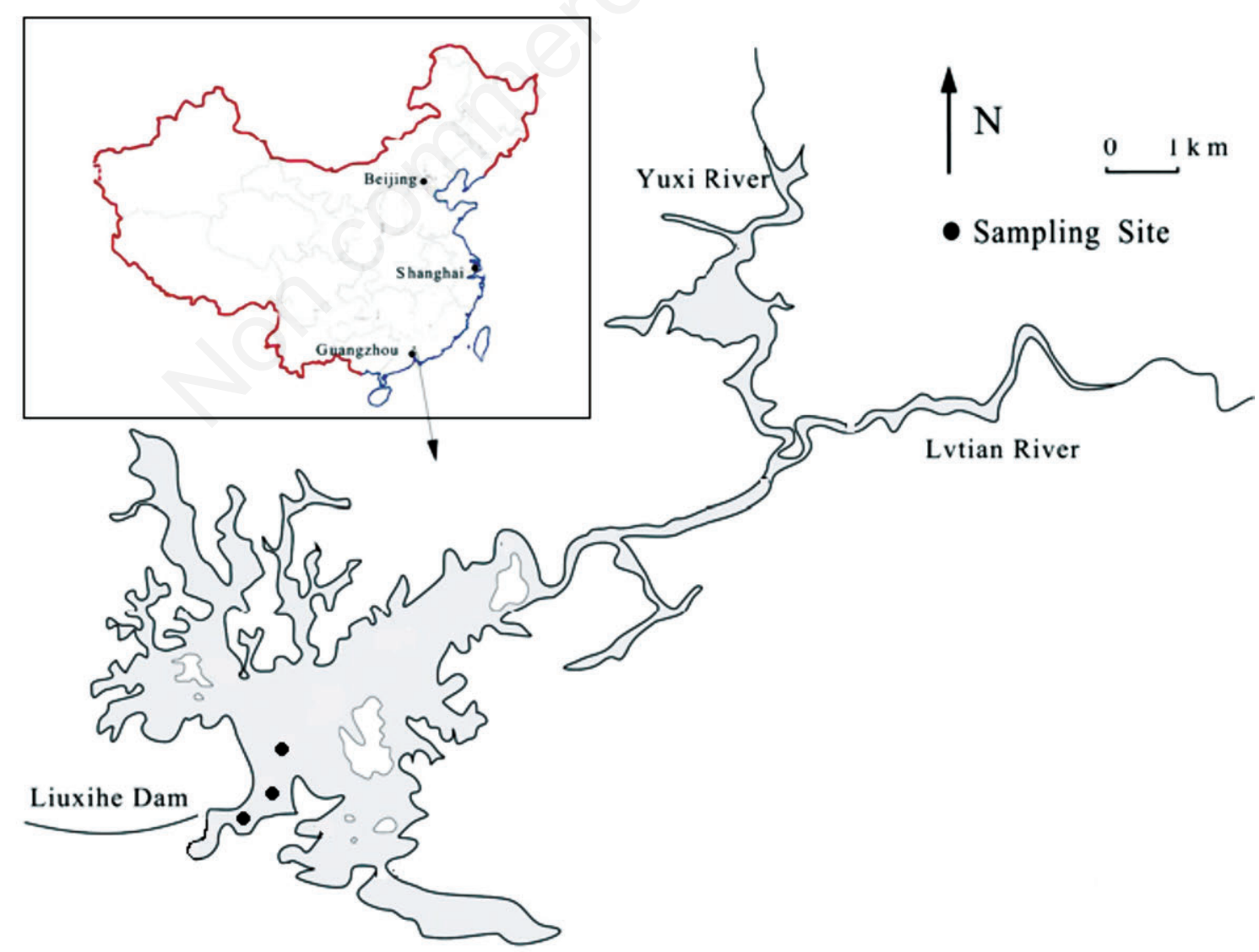

Fig. 1. Morphology of the Liuxihe reservoir in Guangzhou province (upper left box) and the three sampling sites. 
hydropower discharge at $208.5 \mathrm{~m}$ asl. There are two spillways for flooding control: one located under a control gate at $225 \mathrm{~m}$ asl and the other over the dam at $235 \mathrm{~m}$ asl. The thermocline usually distributed at $205 \mathrm{~m}$ asl all year round which occurs around the height of the normal outlet (Wang et al., 2011).

In the present study, intensive epilimnetic withdrawal is defined as the discharge from the spillway under the control gate. The dry season, when precipitation is rare, runs from October to March, while $80 \%$ of annual precipitation occurs in the wet season, from April to September. Mean water retention time is $\sim 170 \mathrm{~d}$, with shorter retention in the wet season (65 d; Lin et al., 2003). The mixing regime is characterized by the following periods: i) dry stratification I in March-April with Zeu/Zmix (euphotic depth:mixing depth ratio; an indicator of light availability following Jensen et al., 1994) $\geq 1$; ii) wet stratification in May-August with Zeu/Zmix $>1$; iii) dry stratification II in September-November with Zeu/Zmix $\leq 1$; and iv) dry isothermy in December-February with Zeu/Zmix $<1$ (Xiao et al., 2011). The reservoir has a high water level ( 230 $\mathrm{m}$ asl in the last fifty years) in wet stratification, and a low water level ( $\sim 220 \mathrm{~m}$ asl in the last fifty years) in dry stratification I and dry stratification II (Lin et al., 2003; Xiao et al., 2011). The average concentrations of total nitrogen (TN), total phosphorus (TP) and chlorophyll $a(\mathrm{Chl}-a)$ in the reservoir are 600, 20 and $1.93 \mu \mathrm{g} \mathrm{L}-1$, respectively, and the average Secchi depth (SD) is $2.9 \mathrm{~m}$ (Lin et al., 2009). Phosphorus is a limiting element for phytoplankton growth in the reservoir [TN/TP:41; dissolved inorganic nitrogen to soluble reactive phosphorus (DIN/SRP):78; Lin et al., 2009] and the phytoplankton community is dominated by diatoms in summer and dinoflagellates in winter (Xiao et al., 2011).

Due to the continuous fluctuations in water level, the reservoir has no submerged vegetation. The bottom of the littoral zone is mainly composed of stone, gravel and sand, whereas the bottom of the open water zone is covered by mud. Surrounding landscapes of the watershed are mainly small hills covered with forest and town land with very little agricultural area.

\section{Sampling and sample analysis}

Water temperature $\left(\mathrm{T}\right.$ in $\left.{ }^{\circ} \mathrm{C}\right)$ and irradiance $\left(\mu \mathrm{mol} \mathrm{m}{ }^{-2}\right.$ $\mathrm{s}^{-1}$ ) were measured with a multi-parameter water quality monitor (YSI Inc., Yellow Springs, OH, USA) at intervals of $1 \mathrm{~m}$ from the surface to near the bottom in a sampling site close to the dam. Hydrological data were provided by the hydropower generation company.

Sampling was carried out weekly in three sites close to the dam (distances less than $2 \mathrm{~km}$ ) in the lacustrine zone from October 12 to November 25, 2010 (Fig. 1). The integrated water samples for nutrients (soluble reactive phosphorus, SRP; dissolved inorganic nitrogen:
$\mathrm{DIN}=\mathrm{NO}_{3}-\mathrm{N}+\mathrm{NO}_{2}-\mathrm{N}+\mathrm{NH}_{4}-\mathrm{N}$; total phosphorus, TP; total nitrogen, $\mathrm{TN})$, chlorophyll-a (Chl- $a$ ) and phytoplankton were collected with a $10 \mathrm{~m}$ length tube sampler at all three sampling sites. Nutrients and Chl- $a$ concentration were measured according to the Chinese National Standards for water quality and to the Environmental Protection Agency of USA (APHA, 1989).

The integrated phytoplankton samples were preserved with $4 \%$ formaldehyde and 1\% Lugol's solution, and stored in dark and cold conditions $\left(4^{\circ} \mathrm{C}\right)$. After sedimentation for at least $48 \mathrm{~h}$, the supernatant was siphoned off with a $2 \mathrm{~mm}$ diameter hose. The residue $(25 \mathrm{~mL})$ was collected and used for counting phytoplankton. At least 400 phytoplankton units placed in a Sedgewick Rafter counting chamber were counted under an Olympus microscope with non-inverted optics at $400 \times$ magnification (APHA, 1989). Three subsamples were counted as one sample. Taxa were determined to the species level wherever possible. To estimate phytoplankton biomass, we measured at least 20 individuals from each species and then applied approximations to similar geometric solids to calculate individual biovolume (Hillebrand et al., 1999). Wet weight of phytoplankton was estimated from the volume of each individual, assuming that $10^{6} \mu \mathrm{m}^{3}$ corresponds to $1 \mu \mathrm{g}$ of wet weight.

Zooplankton was sampled bi-weekly for all three sampling sites. A total of $50 \mathrm{~L}$ water was collected for each sample from the surface to $30 \mathrm{~m}$ depth at $3 \mathrm{~m}$ intervals. Sampled water was filtered into a net with $30-\mu \mathrm{m}$ mesh and then concentrated to $10-20 \mathrm{~mL}$ and preserved with $4 \%$ formaldehyde. Biomass of each species was estimated by measuring the length of at least 20 specimens whenever a sufficient number of animals were available. Individual body wet weights $(\mu \mathrm{g})$ was estimated following the equations of Dumont et al. (1975) and Zhang and Huang (1991). The zooplankton taxa were classed into three groups: i) large crustaceans $(>0.5 \mathrm{~cm})$; ii) small crustaceans $(<0.5 \mathrm{~cm})$; and iii) rotifers.

\section{Data analysis}

Mixing depth was estimated from temperature profiles $\left(\Delta \mathrm{T}>1{ }^{\circ} \mathrm{C} \mathrm{m}^{-1}\right)$. Euphotic depth was estimated from irradiance profiles as $1 \%$ of surface value. The ratio between euphotic and mixing depths (Zeu/Zmix) was used as a measure of light availability (Jensen et al., 1994). Flushing rate $\left(\mathrm{d}^{-1}\right)$ was the ratio of daily discharges $\left(\mathrm{m}^{3}\right)$ to the storage volume $\left(\mathrm{m}^{3}\right)$.

Relative water column stability (RWCS) was calculated following Padisák et al. (2003):

$$
R W C S=\frac{D_{h}-D_{s}}{D_{4}-D_{5}}
$$

where: 
$D_{h}$ is the water density at the bottom of the reservoir $\left(\mathrm{g} \mathrm{cm}^{-3}\right) ; \mathrm{D}_{\mathrm{s}}$ is the water density at the water surface $\left(\mathrm{g} \mathrm{cm}^{-3}\right)$; $\mathrm{D}_{4}$ and $\mathrm{D}_{5}$ are water density at $4^{\circ} \mathrm{C}$ and $5^{\circ} \mathrm{C}\left(\mathrm{g} \mathrm{cm}^{-3}\right)$.

Water density was estimated from temperature values using a Water Density Calculator, which calculates water density at a given temperature between -8 and $108^{\circ} \mathrm{C}$ using 5-point Lagrange interpolation (Senese, 2003).

The rate of community compositional change $(\sigma)$ was calculated according to Lewis (1978):

$$
\sigma=\frac{\sum_{i=1}^{n}\left\{\left[\frac{b_{i}\left(t_{1}\right)}{B\left(t_{1}\right)}\right]-\left[\frac{b_{i}\left(t_{2}\right)}{B\left(t_{2}\right)}\right]\right\}}{t_{1}-t_{2}}
$$

where:

$b_{i}(\mathrm{t})=$ the abundance of $i^{\text {th }}$ species $\left(\right.$ cells $\left.\mathrm{mL}^{-1}\right) ; B(\mathrm{t})=$ the sum of the individuals making up the sampled community (cells $\mathrm{mL}^{-1}$ ); $t_{1}-t_{2}$ is the time (d) difference of the two dates.

The differences in the environmental parameters, phytoplankton biomass and abundance between different periods were tested by ANOVA. The data were transformed into $\log (\mathrm{x}+1)$ prior to analysis to meet statistical criteria for normality and stabilize variances. Spearman correlation analyses were used to determine relationships between two variables. The significance level assumed was $\alpha=0.05$. All statistical analyses were performed with SPSS 15.0 (SPSS for windows, version 15.0). Isopleths was plotted using the software package Surfer 7 (Golden Software, 2000) applying a grid spacing approximating the spatial and temporal distribution of the data.

\section{The model simulation}

The one-dimensional, hydrodynamic model DYRESM coupled dynamically with the Computational Aquatic Ecosystem Dynamics Model (CAEDYM) (Romero et al., 2004) was applied to estimate water temperature (T), suspended sediment (SS) and soluble reactive phosphorus (SRP) distribution in two scenarios: with and without intensive epilimnetic withdrawals. In the first scenario, the actual discharge is used for simulation. In the scenario without epilimnetic withdrawal, the epilimnetic withdrawal is cut off, and only the discharge via the normal outlet is calculated in simulation. We implemented 12 weeks ( 5 weeks more than observation period) as the simulated period from 5 October to 31 December 2010 to test the current and delayed effects of the epilimnetic withdrawal. Boundary and initial conditions (including meteorological and hydrological data, inflow temperature profile, initial temperature, SS and SRP concentration) were based on field measurements.

DYRESM-CAEDYM has been calibrated previously in our reservoir, and could be used as a strategic evaluation tool for Liuxihe reservoir management (Wang et al., 2012b; Wang et al., 2012c). So only a brief description will be included as follow. The concentration of inflow nutrients was estimated by quadratic interpolation on monthly monitoring data. The concentration of inflow suspended particles was estimated by inflow rate and precipitation. DYRESM parameters were based on calibrations in other lakes and reservoirs (Antenucci and Imerito, 2003; Andrew et al., 2007). Settling velocities were calculated as a function of the median diameter and density of the particles according to Stoke's Law in the CAEDYM model. Mineral composition and particle size distribution of suspended particles were measured in 2010 by Wang et al. (2011). To overcome the effects of shape, roundness, and density of particles on the settling velocity, an adjustment factor was introduced to the settling velocity in the Stokes formulation (Chung et al., 2009).

\section{RESULTS}

\section{Hydrodynamics, physical conditions and nutrients}

The water level decreased from 233.6 to $226.4 \mathrm{~m}$ asl over the observation period of October 12 to November 25 (Fig. 2a). The first epilimnetic withdrawal reduced the stored water by about $2.62 \times 10^{8} \mathrm{~m}^{3}$ during the $5^{\text {th }}$ week (November 5 to 8 ), and the second epilimnetic withdrawal reduced about $2.19 \times 10^{8} \mathrm{~m}^{3}$ during the $7^{\text {th }}$ week $(21-23 \mathrm{No}$ vember). Thus, the seven week observation period was divided into two stages: stage 1 that comprised the partial surface vertical mixing period from $1^{\text {st }}$ to $4^{\text {th }}$ week, and stage 2 that comprised the intensive epilimnetic withdrawal period from $5^{\text {th }}$ to $7^{\text {th }}$ week. There was limited inflow (Fig. 2a) to compensate the intensive discharges because in the meantime the precipitation $(15.3 \mathrm{~mm}$ in total) was limited. The highest flushing rates (FR) were 0.0232 and $0.0363 \mathrm{~d}^{-1}$, which occurred in the $5^{\text {th }}$ and $7^{\text {th }}$ week, respectively (Fig. 2b), corresponding to the two epilimnetic withdrawals.

Vertical profiles of water temperature showed that the epilimnetic layer was well mixed at the $3^{\text {rd }}$ week (from surface to about $24 \mathrm{~m}$ in depth) (Fig. 3). The $3^{\text {rd }}$ week, air temperature experienced a sharp $\operatorname{drop}\left(16.4^{\circ} \mathrm{C}\right.$ the $3^{\text {rd }}$ week compared with $24.3^{\circ} \mathrm{C}$ the $2^{\text {nd }}$ week), and the surface water temperature varied with air temperature (Fig. 2b). There was a positive correlation between surface water temperature and air temperature $(\mathrm{R}=0.771 ; \mathrm{P}=0.042)$. Relative water column stability (RWCS) exhibited a greater dependence on surface water temperature. During the observation period, the initial temperature difference between the surface and the bottom layer was $13.2^{\circ} \mathrm{C}$, with a high RWCS value of 323; While the difference of water temperature between the surface and the bottom layer was $7.4^{\circ} \mathrm{C}$, and RWCS value decreased to 162 in the end of the observation period (Fig. 2b).

The availability of light in the water column, expressed by the Zeu/Zmix ratio, could be an important se- 
lective factor for phytoplankton. In the first two weeks, the mixing depth (Zmix) was around 12-13 m. With the cooling of surface water, a deeper Zmix was $24 \mathrm{~m}$ in the $3^{\text {rd }}$ week. The ratio of Zeu/Zmix was $>1$ in the first two weeks. While the ratio became $<1$ after the $3^{\text {rd }}$ week following deepening of the mixing depth, thereby showing a much lower light availability for phytoplankton in the $3^{\text {rd }}$ to $7^{\text {th }}$ week (Fig. 2c).

Nutrient dynamics in the eplimnion of the lacustrine region were complicated during the observation period, which may be affected by factors such as water mixing regime, absorption by phytoplankton and so on. Ranges of TN $\left(\mu \mathrm{g} \mathrm{L}^{-1}\right)$, DIN $\left(\mu \mathrm{g} \mathrm{L}^{-1}\right)$, TP $\left(\mu \mathrm{g} \mathrm{L}^{-1}\right)$ and SRP $\left(\mu \mathrm{g} \mathrm{L}^{-1}\right)$ over the whole observation period were 260.0-535.9, 88.7$316.1,8.0-15.9$, and 1.7-7.2 respectively (Fig. 2d). Integrated SRP concentrations in the eplimnion were about 7 $\mu \mathrm{g} \mathrm{L}^{-1}$ in weeks $1-2$, and significantly decreased to 4 $\mu \mathrm{g} \mathrm{L}^{-1}(\mathrm{~F}=436.6, \mathrm{P}<0.001)$ after the $3^{\text {rd }}$ week, which coincided with the partial surface vertical mixing. Dissolved inorganic nitrogen (DIN) concentrations were significantly lower during stage 2 than that in the $4^{\text {th }}$ week $(\mathrm{F}=25.1, \mathrm{P}<0.001)$, suggesting increasing uptake by phytoplankton.

\section{Model simulation}

The simulation results from DYRESM-CAEDYM model have been proved to be consistent with the measurements, and could be reproduced well (Wang et al., $2012 \mathrm{~b}, 2012 \mathrm{c}$ ). We implemented the model to estimate the dynamics of T, SRP and SS concentration in the scenario with epilimnetic withdrawals (Fig. 4 a1, a2, a3), comparing with the variables in the scenario without epilimnetic withdrawal (Fig. 4 b1, b2, b3). At the end of the observation period $\left(25^{\text {th }}\right.$ November $)$, the epilimnetic withdrawal operation resulted in surface water temperature becoming $1.5 \%$ colder, SRP concentration $0.3 \%$ higher, and SS concentration $3.5 \%$ higher $(=\mathrm{b} / \mathrm{a}-1)$ than when discharges
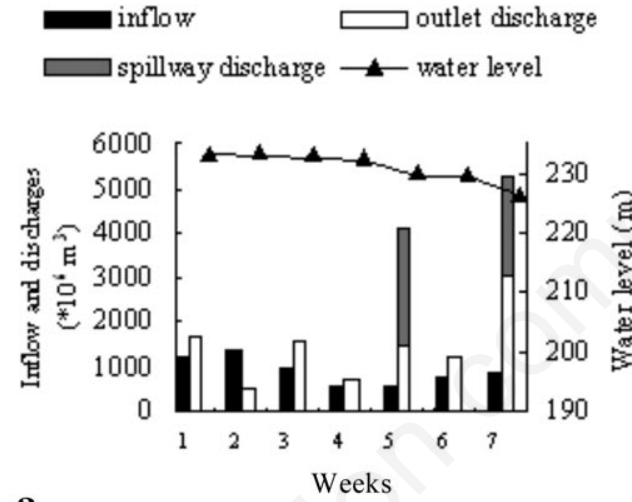

a
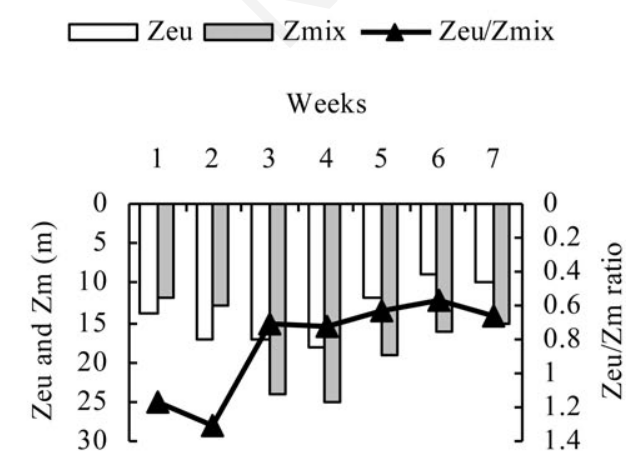
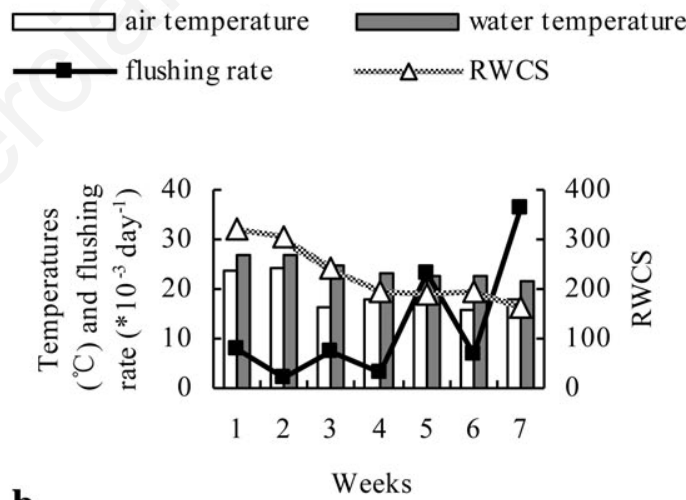

b
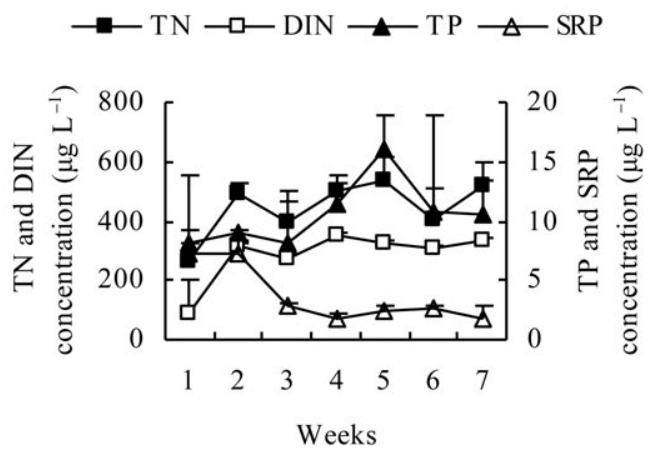

d

Fig. 2. a) Inflow $\left(\times 10^{6} \mathrm{~m}^{3} \mathrm{~d}^{-1}\right)$, normal outlet discharge $\left(\times 10^{6} \mathrm{~m}^{3} \mathrm{~d}^{-1}\right)$, controlled spillway discharge $\left(\times 10^{6} \mathrm{~m}^{3} \mathrm{~d}^{-1}\right)$ and water level (m) (asl); b) trends in air temperature $\left({ }^{\circ} \mathrm{C}\right)$, surface water temperature $\left({ }^{\circ} \mathrm{C}\right)$, flushing rate $\left(\times 10^{-3} \mathrm{~d}^{-1}\right)$ and relative water column stability (RWCS); c) euphotic depth (Zeu: m), mixing depth (Zmix: m) and ratio Zeu/Zmix; d) total phosphorus (TP) $\left(\mu \mathrm{g} \mathrm{L}^{-1}\right)$, soluble reactive phosphorus (SRP) $\left(\mu \mathrm{g} \mathrm{L}^{-1}\right)$, total nitrogen $(\mathrm{TN})\left(\mu \mathrm{g} \mathrm{L}^{-1}\right)$, dissolved inorganic nitrogen (DIN) $\left(\mu \mathrm{g} \mathrm{L}^{-1}\right)$ concentration (means \pm standard error) over seven weeks of observation period. 
occurred without epilimnetic withdrawal. At the end of the simulation period ( $31^{\text {st }}$ December), epilimnetic withdrawals decreased surface water temperature by $1.5 \%$, increased SRP concentration by $0.7 \%$, and promoted SS concentration by $3.6 \%(=\mathrm{b} / \mathrm{a}-1)$.

\section{Phytoplankton community}

Standing crops of phytoplankton showed different trends in the two stages (Fig. 5). Decreases in Chl- $a$ concentration, total abundance and biomass of phytoplankton were observed after the $3^{\text {rd }}$ week, coinciding with the partial surface vertical mixing at the $3^{\text {rd }}$ week. However, the decreasing trend for phytoplankton biomass was reversed in stage 2. Increases in Chl- $a$ concentration, total abundance and biomass of phytoplankton were recorded toward the end of the observation period. Compared to that in the $3^{\text {rd }}-5^{\text {th }}$ weeks, total phytoplankton biomass and abundance significantly increased (phytoplankton biomass: $\mathrm{F}=8.1, \mathrm{P}=0.017$; phytoplankton abundance: $\mathrm{F}=28.2$, $\mathrm{P}<0.001)$ at the $6^{\text {th }}$ week. Results from Spearman correlation analyses showed that the decreased phytoplankton biomass was positively correlated with the declined water temperature and SRP (Tab. 1).

During the observation period, 47 taxa were identified, distributed in seven taxonomic groups: Chlorophyceae (28), Bacillariophyceae (8), Cyanophyceae (6), Dinophyceae (2), Cryptophyceae (1), Euglenophyceae (1), Chrysophyceae (1). Bacillariophyta (mainly Cyclotella meneghiniana and Rhizosolenia longiseta) and Chlorophyta (mainly Ankistrodesmus spiralis and Coelastrum microporum) biomass contributed 31.8 and $45.8 \%$ of total phytoplankton biomass in the initial week, respectively. Phytoplankton community of major taxonomic groups did

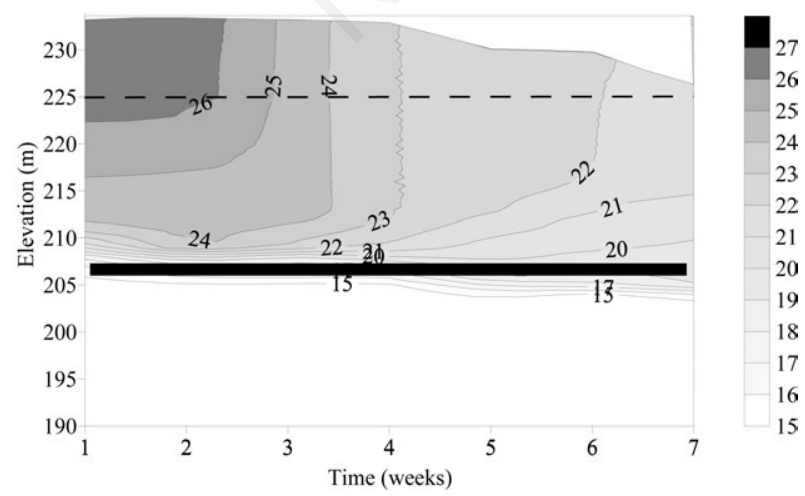

Fig. 3. Depth-time isopleths of water temperature $\left({ }^{\circ} \mathrm{C}\right)$ over seven weeks of observation period. Solid line indicates elevation of the normal outlet $(208.5 \mathrm{~m}$ asl; $18.5 \mathrm{~m}$ depth at the dam). Dash line indicates elevation of the controlled spillway ( $225 \mathrm{~m}$ asl; $45 \mathrm{~m}$ depth at the dam). not vary greatly in biomass composition during the observation period. However, in stage 2, Bacillariophyta (mainly Cyclotella meneghiniana and Rhizosolenia longiseta) biomass decreased their relative importance, whereas Chrysophyta (Dinobryon sp.) biomass showed a more distribution than that in stage 1. A clear transformation between the two stages can be seen from the rates of compositional change of phytoplankton community, with low values (0.066-0.077) in stage 1 and high values (0.088-0.103) in stage 2.

\section{Zooplankton}

Zooplankton species composition did not vary greatly (ANOVA, $\mathrm{P}>0.05$ ). The large crustaceans were dominated by Phyllodiaptomus tunguidus, Moina micrura, and Mesocyclops thermocyclopoides, which together accounted for about $60 \%$ of total zooplankton biomass. The small crustaceans were represented by Bosmina fatalis, copepodites and Tropocyclops bopingi, which together accounted for about $40 \%$ of total zooplankton biomass. Rotifers (mainly Keratella cochlearis and Trichocerca stylata) were also present but with low biomass.

The biomass of the large crustaceans decreased from $324.9 \mu \mathrm{g} \mathrm{L}^{-1}$ at the $3^{\text {rd }}$ week to $115.4 \mu \mathrm{g} \mathrm{L}^{-1}$ at the $7^{\text {th }}$ week. The total abundance and biomass of zooplankton also showed an evident decline in stage 2. Overall, zooplankton with high biomass of $397.7 \mu \mathrm{g} \mathrm{L}^{-1}$ at the $3^{\text {rd }}$ week and the low biomass of $197.7 \mu \mathrm{g} \mathrm{L}^{-1}$ at the $7^{\text {th }}$ week; total abundance followed the similar pattern, decreasing from 74.0 to 49.5 individuals $\mathrm{L}^{-1}$. Correlation results showed that the flushing rate, induced by intensive epilimnetic withdrawal, was probably responsible for the decrease in large crustacean biomass (Tab. 1).

\section{DISCUSSION}

The observation period of seven weeks in Liuxihe reservoir was divided into two stages: stage $1\left(1^{\text {st }}-4^{\text {th }}\right.$ week) of partial surface vertical mixing and stage $2\left(5^{\text {th }}\right.$ $7^{\text {th }}$ week) of intensive epilimnetic withdrawal. In stage 1 , the sharp drop of air temperature at the $3^{\text {rd }}$ week contributed to the partial surface vertical mixing in the epilimnion (from surface to about $24 \mathrm{~m}$ in depth) without breaking the thermal stratification. In the reservoir, large fluctuations in water level constrain the growth of macrohydrophytes in the littoral zone. The shoreline therefore becomes a source of suspended particles. When partial surface vertical mixing occurs, these suspended particles from the shore enter easily the pelagic zone, reducing light availability of phytoplankton. Meanwhile, poor red loam in Liuxihe reservoir is rich in iron, and could combine with phosphate (Lin et al., 2009). Particulate matter from poor red loam could remove SRP from the surface layer. Indirect evidences indicated that the decreased RWCS 
was positively correlated with the Zeu/Zmix ratio $(\mathrm{R}=0.786 ; \mathrm{P}<0.001)$ and $\mathrm{SRP}(\mathrm{R}=0.43 ; \mathrm{P}=0.05)$ during the observation period, suggesting that the partial vertical mixing may be followed by the declining Zeu/Zmix ratio and SRP. Therefore, the air temperature-driven mixing decreased water temperature, Zeu/Zmix ratio, and SRP in the epilimnion, ultimately, accounted for the decline of Chl$a$ and phytoplankton biomass in stage 1 (Tab. 1). This is consistent with the view that mixing regime exerts a basic constraint for phytoplankton biomass, and temperature is the major factor controlling the mixing regime (Çalişkan and Elçi, 2009; Xu et al., 2012). A study in Faxinal reservoir, a warm monomictic impoundment in subtropical southern Brazil for example, showed that the mixing regime is the main determining force driving the seasonal dynamics of phytoplankton biomass (Becker et al., 2009).

It is widely accepted that the chemical (nutrients, particularly phosphorus) and physical (temperature, underwater light climate) conditions could affect the phytoplankton biomass (Reynolds, 2006). Performances of the chemical and physical conditions in our observation were found to be affected by many external factors including mixing regime, absorption by phytoplankton, as well as by epilimnetic withdrawal. The effects of these factors, however, were mixed and difficult to be recognized. DYRESMCAEDYM model, fortunately, is able to mirror the single effect of intensive epilimnetic withdrawal on water temperature, SRP and SS concentration, excluding the influences

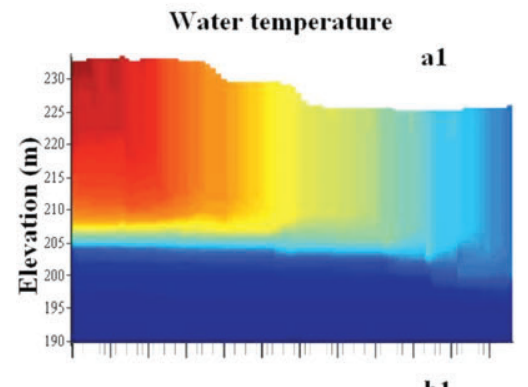

b1

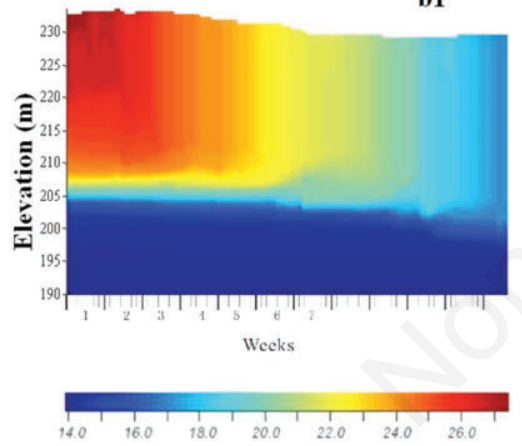

SRP concentration

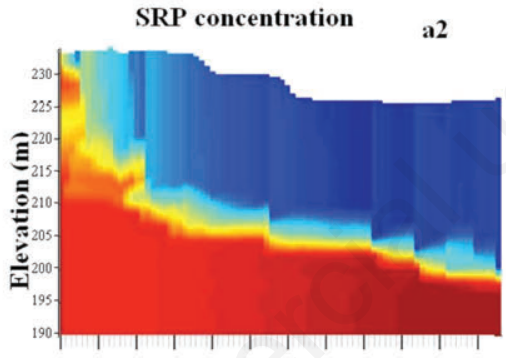

b2

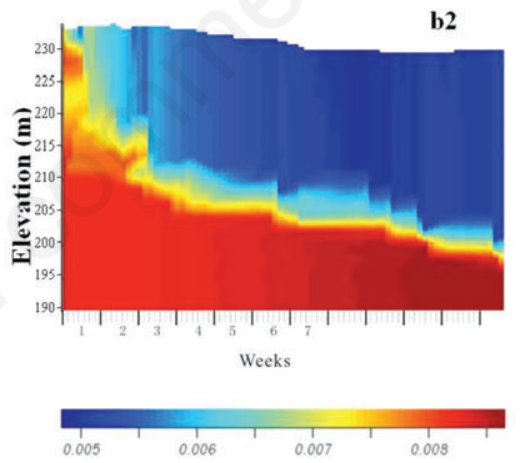

SS concentration

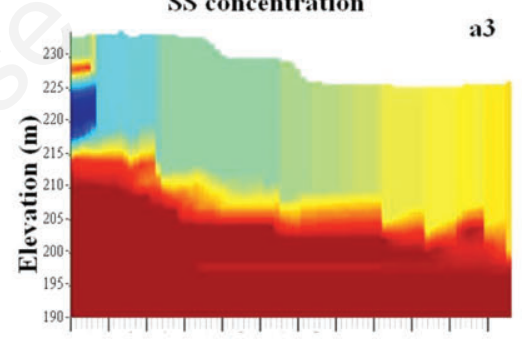

b3

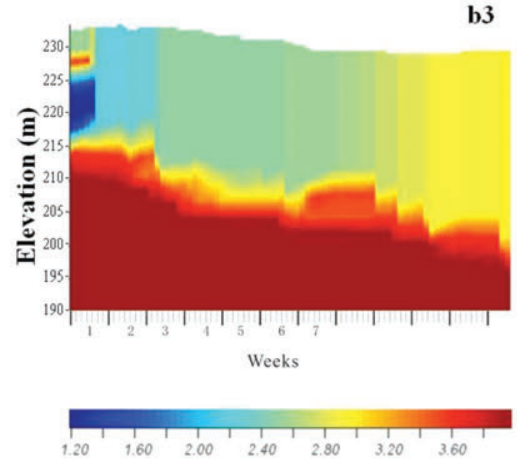

Fig. 4. Simulated water temperature $\left({ }^{\circ} \mathrm{C}\right)$, soluble reactive phosphorus (SRP) concentration $\left(\mu \mathrm{g} \mathrm{L}^{-1}\right)$ and suspended sediment (SS) concentration ( $\mu \mathrm{g} \mathrm{L}^{-1}$ ) with (a) and without (b) intensive epilimnetic withdrawals from October 5 to December 30, 2010.

Tab. 1. Significant Spearman rank correlation between plankton biomass $\left(\mu \mathrm{g} \mathrm{L}^{-1}\right)$ and environmental variables.

\begin{tabular}{llllll}
\hline $\begin{array}{l}\text { Abiotic } \\
\text { variables }\end{array}$ & $\begin{array}{l}\text { Correlation with } \\
\text { phytoplankton biomass }\end{array}$ & $\begin{array}{l}\text { Sig. } \\
(2 \text {-tailed })\end{array}$ & $\begin{array}{l}\text { Abiotic } \\
\text { variables }\end{array}$ & $\begin{array}{l}\text { Correlation with } \\
\text { large crustacean biomass }\end{array}$ & $\begin{array}{l}\text { Sig. } \\
(2 \text {-tailed) }\end{array}$ \\
\hline T & $0.495^{*}$ & 0.022 & T & 0.173 & 0.591 \\
SS & -0.377 & 0.092 & SS & -0.173 & 0.591 \\
SRP & $0.459^{*}$ & 0.036 & SRP & $-0.785^{* *}$ & 0.002 \\
DIN & -0.366 & 0.103 & DIN & -0.173 & 0.591 \\
Zeu/Zmix & 0.433 & 0.051 & Flushing rate & $-0.605^{*}$ & 0.037 \\
& & & Chl-a & -0.591 & 0.056
\end{tabular}

T, water temperature $\left({ }^{\circ} \mathrm{C}\right) ; S S$, suspended sediment $\left(\mu \mathrm{g} L^{-1}\right)$; SRP, soluble reactive phosphorus $\left(\mu g L^{-1}\right)$; DIN, dissolved inorganic nitrogen $\left(\mu g L^{-1}\right)$; Zeu/Zmix, euphotic depth:mixing depth ratio. ${ }^{*} P<0.05 ;{ }^{* *} P<0.01$. 
of weather and other hydrodynamic conditions. In the model simulation, except for water level, no obvious changes were observed in water temperature, SRP and SS concentration between the two scenarios during stage 2 (Fig. 4). Therefore, we infer that the changes of water temperature, SRP and SS concentration in the observation period were mainly driven by a seasonal pattern, not by the intensive epilimnetic withdrawal. It is interesting, however, that the intensive epilimnetic withdrawal appeared to significantly affect phytoplankton standing crops and reverse the decreasing trend in stage 2 .

The flushing effect of epilimnetic withdrawal on phytoplankton and zooplankton biomass varies with flushing rates. Søballe and Kimmel (1987) suggested that the flushing effect on both phytoplankton and zooplankton biomass becomes apparent when a threshold flushing rate of 0.01-0.02 $\mathrm{d}^{-1}$ is exceeded. However, Perry et al. (1990) reported that standing crops were limited by rates of cell export only at extremely high flushing rates $\left(>0.25 \mathrm{~d}^{-1}\right)$, and that the effects were not pronounced at $0.1-0.17 \mathrm{~d}^{-1}$ flushing rates. Rennella and Quirós (2006) argued that phytoplankton biomass could even reach its highest level when flushing rate is intermediate, and weakened grazing effects are possible underlying cause. In Liuxihe reservoir, the flushing rate did not appear high enough to suppress phytoplankton standing biomass; While large crustaceans with longer generation times were obviously removed by flushing (flushing rate: $0.0232-0.0363 \mathrm{~d}^{-1}$ ) during stage 2 (the epilimnetic withdrawal period). Decreased water temperature was probably not responsible for the decrease in large crustaceans (Tab. 1), as temperature was still high enough (above $20^{\circ} \mathrm{C}$ ) for zooplankton to grow rapidly (Lin et al., 2011).

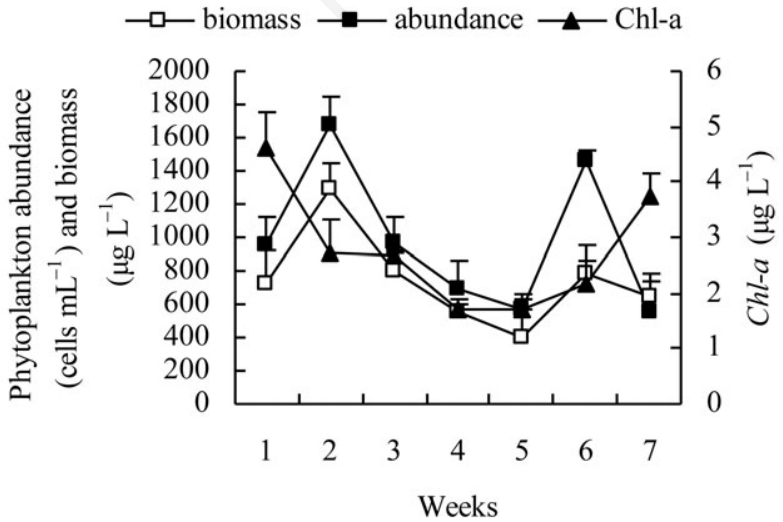

Fig. 5. Trends in Chl- $a$ concentration $\left(\mu \mathrm{g} \mathrm{L}^{-1}\right)$, phytoplankton abundance (cells $\mathrm{mL}^{-1}$ ) and biomass $\left(\mu \mathrm{g} \mathrm{L}^{-1}\right)$ for the three sampling sites (means \pm standard error) over seven weeks of observation period.
In general, the standing crop of phytoplankton is dependent on growth and loss rates. Nutrients and water temperature are the main factors influencing phytoplankton growth, whereas flushing, grazing and sinking contribute to the loss (Reynolds, 2006). In our observation, the decreasing water temperature, low SRP concentration, low Zeu/Zmix ratio, and the intensive flushing could have suppressed phytoplankton biomass as expect during stage 2 . However, phytoplankton standing crop was increased in stage 2, which could only be attributed to the decrease in zooplankton grazing pressure caused by declining population of large crustaceans. If the reduced grazing pressure from zooplankton is the main factor promoting phytoplankton biomass during the epilimnetic withdrawal period, a high Chl- $a$ :SRP ratio would be expected. Indeed, the Chl- $a$ :SRP ratio was significantly higher at the $7^{\text {th }}$ week (LSD, $\mathrm{P}<0.001$ ) than that at the $1^{\text {st }}$ to $6^{\text {th }}$ week. Furthermore, the effects of reduced grazing pressure extended till December, as shown by a high phytoplankton biomass in December 26 (phytoplankton biomass increased to 1155.4 $\mu \mathrm{g} \mathrm{L}^{-1}$; Chl $-a$ concentration increased to $4.52 \mu \mathrm{g} \mathrm{L}^{-1}$ ). Till the end of the December, however, implementation of epilimnetic withdrawal could not bring about obvious change for water temperature, SRP and SS concentration (Fig. 4). Surface water temperature fell to $18.25^{\circ} \mathrm{C}$, SRP concentration was $4.2 \mu \mathrm{g} \mathrm{L}^{-1}$, Zeu/Zmix fell to 0.43 , and zooplankton biomass remained at a low level (199.8 $\mu \mathrm{g} \mathrm{L}^{-1}$ ). The reduced grazing pressure, therefore, appears to be the main reason for the increase in phytoplankton standing crop during the epilimnetic withdrawal period.

\section{CONCLUSIONS}

Liuxihe reservoir is a warm monomictic reservoir with a very short mixing period in January/February (Xiao et al., 2011). In contrast to discharges without epilimnetic withdrawal, epilimnetic withdrawal releases the warmer water and decreases water column stability, which slightly enhances partial vertical mixing in the epilimnion and may provide renewal of environment for phytoplankton community succession. The decreased population of large crustaceans caused by flushing, ultimately, could be responsible for the high phytoplankton standing crop during the epilimnetic withdrawal period. We suggest that intensive epilimnetic withdrawals in autumn can slightly accelerate partial surface vertical mixing in the epilimnion, remove large crustaceans and thereby promote high standing crop of phytoplankton in the tropics and subtropics.

\section{ACKNOWLEDGMENTS}

Support by grants from Chinese NSF (Nos. 31170437, U0733007) is greatly appreciated. We are grateful to Profs. Ken Chan from Australia, Henri Dumont of Ghent University in Belgium, Bo Zeng of Southwest University 
in China, and two anonymous referees for reading the manuscript and providing useful comments. We also thank all colleagues and students in the field station for their help with sampling.

\section{REFERENCES}

Andrew JT, David PH, Norman DY, 2007. Calibrating the Dynamic Reservoir Simulation Model (DYRESM) and filling required data gaps for one-dimensional thermal profile predictions in a boreal lake. Limnol. Oceanogr. 5:484-494.

Antenucci J, Imerito A, 2003. The CWR Dynamic Reservoir Simulation Model DYRESM: User Manual. Centre for Water Research, The University of Western Australia.

APHA, 1995. Standard methods for the examination of water and wastewater. American Water Works Association and Water Pollution Control Federation, Washington.

Barbiero RP, James W, Barko JW, 1997. The effects of a change in withdrawal operations on phytoplankton and nutrient dynamics in Eau Galle reservoir, Wisconsin (USA). Int. Rev. Hydrobiol. 82:531-543.

Becker V, Huszar VLM, Crossetti LO, 2009. Responses of phytoplankton functional groups to the mixing regime in a deep subtropical reservoir. Hydrobiologia 628:137-151.

Burford MA, Green SA, Cook AJ, Johnson SA, Kerr JG, O'Brien KR, 2012. Sources and fate of nutrients in a subtropical reservoir. Aquat. Sci. 74:179-190.

Calijuri MC, Dos Santos ACA, Jati S, 2002. Temporal changes in the phytoplankton community structure in a tropical and eutrophic reservoir (Barra Bonita, S.P.- Brazil). J. Plankt. Res. 24: 617-634.

Çalişkan A, Elçi Ş, 2009. Effects of selective withdrawal on hydrodynamics of a stratified reservoir. Wat. Res. Manage. 23:1257-1273.

Cheng WF, Kao SJ, 2008. Effects of climate events driven hydrodynamics on dissolved oxygen in a subtropical deep reservoir in Taiwan. Sci. Total Environ. 393:326-332.

Chien YC, Wu SC, Wu JT, 2009. Identification of physical parameters controlling the dominance of algal species in a subtropical reservoir. Wat. Sci. Tech. 60:1779-1786.

Chung SW, Hipsey MR, Imberger J, 2009. Modelling the propagation of turbid density inflows into a stratified lake: Daecheong Reservoir, Korea. Environ. Modell. Soft. 24:1467-1482.

Cooke GD, Welch EB, Peterson SA, Newroth PR, 1993. Restoration and management of lakes and reservoirs. Lews Publ., Boca Raton.

Dumont HJ, Van de Velde I, Dumont S, 1975. The dry weight estimate of biomass in a selection of cladocera, copepoda and rotifera from the plankton, periphyton and benthos of continental waters. Oecologia 19:75-97.

Hamilton DP, Schladow SG, 1997. Prediction of water quality in lakes and reservoirs. I. Model description. Ecol. Modell. 96:91-110.

Han BP, Armengo J, Garcia JC, Comerma M, Roura M, Dolz J, Straskraba M, 2000. The thermal structure of Sau Reservoir (NE: Spain): a simulation approach. Ecol. Modell. 125:109122.

Han BP, Liu Z, 2011. Tropical and sub-tropical reservoir limnology in China: theory and practice. Springer.
Hillebrand H, Duerselen CD, Kirschtel D, Pollingher U, Zohary T, 1999. Biovolume calculation for pelagic and benthic microalgae. J. Phycol. 35:403-424.

Jensen P, Jeppesen E, Olrik K, Kristensen P, 1994. Impact of nutrients and physical factors on the shift from cyanobacterial to chlorophyte dominance in shallow Danish lakes. Can. J. Fish Aquat. Sci. 51:1692-1699.

Lewis WM Jr, 1978. Analysis of succession in a tropical phytoplankton community and a new measure of succession rate. Am. Nat. 112:401-414.

Lin GE, Wang T, Lin QQ, Han BP, 2009. Spatial pattern and temporal dynamics of limnological variables in Liuxihe Reservoir, Guangdong. J. Lake Sci. 21:87-394.

Lin QQ, Han BP, Dumont HJ, 2011. Seasonal dynamics of Daphnia galeata in a reservoir at the edge of the tropics before and after yearly stocking with bighead carp, p. 53-58. In: B.P. Ha and Z. Liu (eds.), Tropical and Sub-Tropical Reservoir Limnology in China, Monographiae Biologicae, Springer Netherlands.

Lin QQ, Hu R, Han BP, 2003. Effect of hydrodynamics on nutrient and phytoplankton distribution in Liuxihe Reservoir. Acta Ecol. Sinica. 11:278-2284.

Naselli-Flores L, Barone R, 2005. Water-level fluctuations in Mediterranean reservoirs: setting a dewatering threshold as a management tool to improve water quality. Hydrobiologia 548:85-99.

Nürnberg GK, 2007. Lake responses to long-term hypolimnetic withdrawal treatments. Lake Reserv. Manage. 23:388-409.

Pace ML, Findlay EG, Lints D, 1992. Zooplankton in advective environments: the Hudson River community and a comparative analysis. Can J. Fish Aquat. Sci. 49:1060-1069.

Padisák J, Scheffler W, Kasprzak P, Koschel R, Krienitz L, 2003. Interannual variability in the phytoplankton composition of Lake Stechlin (1994-2000). Adv. Limnol. 58:101-133.

Perry SA, Perry WB, Simmons JGM, 1990. Bacterioplankton and phytoplankton populations in a rapidly-flushed eutrophic reservoir. Int. Rev. Hydrobiol. 75:27-44.

Rennella AM, Quirós R, 2006. The effects of hydrology on plankton biomass in shallow lakes of the Pampa Plain. Hydrobiologia 556:181-191.

Reynolds CS, 2006. The ecology of phytoplankton. Cambridge University Press, London.

Romero JR, Antenucci JP, Imberger J, 2004. One and three dimensional biogeochemical simulations of two differing reservoirs. Ecol. Modell. 174:143-160.

Senese FA, 2003. Water density calculator. Available from: http://antoine.frostburg.edu/chem/senese/javascript/waterdensity.html

Søballe DM, Kimmel BL, 1987. A large-scale comparison of factors influencing phytoplankton abundance in rivers, lakes, and impoundments. Ecology 68:1943-1954.

Wang S, Qian X, Han BP, Luo LC, Hamilton DP, 2012a. Effects of local climate and hydrological conditions on the thermal regime of a reservoir at Tropic of Cancer, in southern China. Water Res. 46:2951-2604.

Wang S, Qian X, Han BP, Luo LC, Ye R, Xiong W, 2012b. Effects of different operational modes on the flood-induced turbidity current of a canyon-shaped reservoir: case study on Liuxihe Reservoir, South China. Hydrol. Process. (in press).

Wang S, Qian X, Han BP, Wang QH, Ding ZF, 2011. Physical 
limnology of a typical sub-tropical reservoir in south China. Lake Reserv. Manage. 27:149-161.

Wang S, Qian X, Wang QH, Xiong W, 2012c. Modeling turbidity intrusion processes in flooding season of a canyonshaped reservoir, South China. Procedia Environmental Sciences 13:1327-1337.

Xiao LJ, Wang T, Hu R, Han BP, Wang S, Qian X, Padisák J, 2011. Succession of phytoplankton functional groups regu- lated by monsoonal hydrology in a large canyon-shaped reservoir. Water Res. 45:5099-5109.

Xu Y, Cai Q, Shao M, Han X, 2012. Patterns of asynchrony for phytoplankton fluctuations from reservoir mainstream to a tributary bay in a giant dendritic reservoir (Three Gorges Reservoir, China). Aquat. Sci. 74:287-300.

Zhang ZS, Huang XF, 1991. Plankton researches in freshwater. Science Press, Beijing. 